\title{
EFFECT OF AGGREGATE SOURCE AND GRADATION ON THE RESILIENT BEHAVIOR OF BASES AGGREGATE
}

\author{
Abdulrahman Al-Suhaibani \\ King Saud University, Riyadh, Saudi Arabia
}

\begin{abstract}
The recent AASHTO Guide for the structural design of flexible pavement uses resilient modulus as the input property for different pavement layers. Different aggregate sources as well as the relatively wide range of gradation (as set by specifications of the Saudi Ministry of Transportation) of aggregates to be used for base layer make it necessary to study the effect of these two factors on the resilient behavior of these aggregates. Two models were used to describe the resilient behavior of tested aggregates. The main regression constants $(\mathrm{K} 1$ and $\mathrm{K} 3$ ) of both models were found to be significantly affected by aggregate type but not by aggregate gradation. Regression models were also developed to relate these constants to aggregates' physical properties.

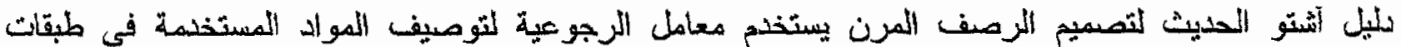

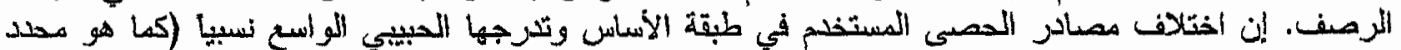

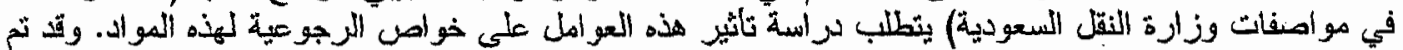

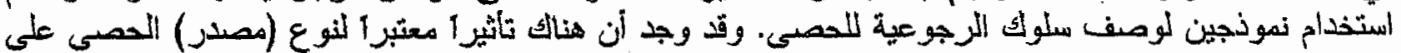

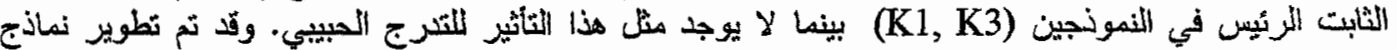
انحدارية لربط هذه الثو ابت بالخواص الفيزيائية للحصى.
\end{abstract}

Keywords: Aggregate, Aggregate Type, Aggregate Gradation, Resilient Modulus, Aggregate Properties.

\section{INTRODUCTION}

In recent pavement design methods, materials used in different layers are characterized in terms of resilient modulus $\left(\mathrm{M}_{\mathrm{R}}\right)$. This includes subgrade, subbase, base and surface layers. As far as unbound base layer is concerned, variation of aggregate gradation could have a significant effect on aggregate resilient modulus. The Source of aggregate might have an effect on the values of resilient modulus of aggregate. In this paper, the effect of aggregate source and gradation was investigated.

A number of studies have investigated the aggregate resilient behavior (Rada and Witczak (1981), Uzan, J. (1985), Heydinger et al. (1997) and Tian et al. (1998)). Some of these studies were concerned with the effect of aggregate gradation, while others investigated the aggregate source effect. Rada and Witczak (1981) investigated 271 test results for granular materials resilient modulus. Six different granular materials were evaluated. They used the bulk stress to model $M_{R}\left(M_{R}=K_{1} \theta^{K 2}\right)$ behavior and they found that the gradation effect on values of $K_{1}$ and $\mathrm{K}_{2}$ depends on the type of aggregate.
Uzan, J. (1985) characterized granular material. He concentrated on modeling the resilient behavior using bulk and deviator stresses as independent variables. Chen et al. (1994) studied the variability of $M_{R}$ values due to aggregate source and testing method. He reported that variability up to $50 \%$ was found due to aggregate source and the variability due to the testing procedure was higher than that due to the aggregate source. Heydinger et al. (1997) presented a study in which the effect of type and gradation of aggregate on resilient behavior was investigated. There was significant variation in $M_{R}$ due to aggregate type, while the variation due to aggregate gradation was less. Tian et al. (1998) found that the aggregate gradation effect on $\mathrm{M}_{\mathrm{R}}$ depends on aggregate type. There was a variation up to $50 \%$ for some types of investigated aggregates due to changes in gradation.

\section{OBJECTIVES AND SCOPE OF WORK}

Since aggregate sources are continuously changing as aggregate quarries are depleted and other mines are used. Furthermore, aggregate at different regions of the Kingdom are of different types. In addition, the 
range of the acceptable gradation for aggregates to be used as base courses is relatively wide and variation in properties is expected. Therefore, the objectives of this paper are to study the effect, if any, of changing the source and gradation of aggregates to be used as base courses on resilient behavior of these materials.

\section{EXPERIMENTAL WORK}

Three sources of aggregates from three regions in the Kingdom, namely; Eastern, Central (Riyadh) and Western regions, were obtained and used in this study. Each of the aggregates was subjected to various characterization tests. These tests include specific gravity; absorption and Los Angles abrasion test. Results are shown in Table 1. The Eastern and Central aggregates were of limestone origin, while the western aggregate was of basalt origin.

Table 1 MOT Grading III for Aggregate Bases (MRDTM 204)

\begin{tabular}{|c|c|c|c|c|}
\hline \multirow{2}{*}{$\begin{array}{c}\text { Sieve } \\
\text { Size }\end{array}$} & $\begin{array}{c}\text { Grading } \\
\text { III } \\
\text { limits }\end{array}$ & \multicolumn{3}{|c|}{ Percent Passing } \\
\cline { 3 - 5 } & $\begin{array}{c}\text { Upper } \\
\text { Limit }\end{array}$ & $\begin{array}{c}\text { Mid- } \\
\text { point }\end{array}$ & $\begin{array}{c}\text { Lower } \\
\text { Limit }\end{array}$ \\
\hline $\begin{array}{c}25 \mathrm{~mm} \\
(1 \mathrm{inch})\end{array}$ & 100 & 100 & 100 & 100 \\
\hline $\begin{array}{c}19 \mathrm{~mm} \\
(3 / 4 \mathrm{inch})\end{array}$ & $70-100$ & 100 & 85 & 70 \\
\hline $\begin{array}{c}4.75 \mathrm{~mm} \\
(\mathrm{No.4})\end{array}$ & $35-65$ & 65 & 50 & 35 \\
\hline $\begin{array}{c}0.425 \mathrm{~mm} \\
(\mathrm{No.40)}\end{array}$ & $15-25$ & 25 & 20 & 15 \\
\hline $\begin{array}{c}0.075 \mathrm{~mm} \\
(\mathrm{No.200)})\end{array}$ & $3-10$ & 10 & 6.5 & 3 \\
\hline
\end{tabular}

Aggregates were obtained in three sizes; coarse, fine and filler. They were sieved and recombined according to base course gradation III as specified by Ministry of Transportation (MOT). Within the gradation three levels were used; upper limit, lower limit and at midpoint between the upper and lower limits. The three gradation levels are shown in Table 1. At each gradation level, aggregates were compacted using modified Proctor method. Maximum dry densities and optimum moisture contents are shown in Table 2.

Using maximum dry density and optimum moisture content, for each aggregate level and for each of the three aggregate types, samples were prepared and tested for resilient modulus and unconfined compressive strength. The results are shown in Table 3. The unconfined compressive strength for the Central aggregate is much higher than the other two sources, especially for midpoint and lower gradations (possesses higher percentages of fines). Unconfined compressive strength values for Eastern and Western aggregates are somewhat close to each other. The unconfined compressive strength is related to cohesion component, therefore its values increase as the clay quantity increases. This is noticeable by comparing unconfined compressive strength for upper limit (high fines), midpoint (medium fines) and low limit (low fines) gradations in Table 3.

Table 2 Properties of Aggregates from Different Sources

\begin{tabular}{|c|c|c|c|c|}
\hline \multirow{2}{*}{$\begin{array}{l}\text { Aggregate } \\
\text { Source }\end{array}$} & \multirow{2}{*}{ Aggregate Property } & \multicolumn{3}{|c|}{ Gradation } \\
\hline & & Upper & Middle & Lower \\
\hline \multirow{6}{*}{ Central } & Bulk Sp. Gr. & 2.535 & 2.555 & 2.564 \\
\hline & Apparent Sp. Gr. & 2.721 & 2.693 & 2.691 \\
\hline & Absorption, $\%$ & 2.702 & 2.018 & 1.838 \\
\hline & Abrasion, $\%$ loss & 30.35 & 30.35 & 30.35 \\
\hline & $\begin{array}{l}\text { Optimum Moisture } \\
\text { Content, \% }\end{array}$ & 6.4 & 6.35 & 6.2 \\
\hline & $\begin{array}{l}\text { Maximum Dry } \\
\text { Density, } \mathrm{Kg} / \mathrm{m}^{3}\end{array}$ & 2.18 & 2.22 & 2.25 \\
\hline \multirow{6}{*}{ Eastern } & Bulk Sp. Gr. & 2.503 & 2.567 & 2.548 \\
\hline & Apparent Sp. Gr. & 2.698 & 2.684 & 2.638 \\
\hline & Absorption, $\%$ & 2.881 & 2.183 & 1.927 \\
\hline & Abrasion, \% loss & 33.43 & 33.43 & 33.43 \\
\hline & $\begin{array}{l}\text { Optimum Moisture } \\
\text { Content, \% }\end{array}$ & 6.8 & 6.3 & 6.2 \\
\hline & $\begin{array}{l}\text { Maximum Dry } \\
\text { Density, } \mathrm{Kg} / \mathrm{m}^{3}\end{array}$ & 2.09 & 2.22 & 2.25 \\
\hline \multirow{6}{*}{ Western } & Bulk Sp. Gr. & 2.841 & 2.856 & 2.855 \\
\hline & Apparent Sp. Gr. & 2.936 & 2.945 & 2.938 \\
\hline & Absorption, $\%$ & 1.127 & 1.045 & 0.990 \\
\hline & Abrasion, $\%$ loss & 19.5 & 19.5 & 19.5 \\
\hline & $\begin{array}{l}\text { Optimum Moisture } \\
\text { Content, } \%\end{array}$ & 5.4 & 5.0 & 4.7 \\
\hline & $\begin{array}{l}\text { Maximum Dry } \\
\text { Density, } \mathrm{Kg} / \mathrm{m}^{3}\end{array}$ & 2.38 & 2,40 & 2.40 \\
\hline
\end{tabular}

Table 3 Unconfined Compressive Strength of Aggregates

\begin{tabular}{|c|c|c|c|}
\hline \multirow{2}{*}{$\begin{array}{c}\text { Aggregate } \\
\text { Source }\end{array}$} & \multicolumn{3}{|c|}{ Gradation } \\
\cline { 2 - 4 } & Upper limit & Midpoint & Lower limit \\
\hline Central & $201.00^{*}$ & 172.55 & $\mathbf{8 8 . 6 0}$ \\
\hline Eastern & 89.50 & 78.84 & 50.88 \\
\hline Western & 93.20 & $\mathbf{8 1 . 4 8}$ & 73.35 \\
\hline
\end{tabular}

* in $\mathrm{KPa}$

\section{RESULTS OF RESILIENT MODULUS TESTING}

Resilient modulus test is a dynamic test that is assumed to simulate traffic loading that the pavement material is subjected to in the field. It is assumed that pavement materials behave as an elastic material if the loading period is relatively short such as moving vehicle at the range of speeds usually encountered in the field. Elastic materials deform due to loading but this deformation almost fully recovered after load removal. It is this concept that is used in resilient 
modulus testing where the dynamic stress is divided by resilient (recovered) strain to obtain the resilient modulus. Unbound materials are relatively weak and can not withstand repeated loading without lateral confinement, thus confining pressure is applied on the specimen. In this study, the resilient modulus device manufactured by OEM, Inc., Corvallis, Oregon, USA was used to measure resilient modulus. A schematic diagram of the apparatus is shown in Figure 1.

The stress sequence recommended by AASHTO Test T 294-92 I method for unbound bases was used. The stress sequence is shown in Table 4. Loading time equals $0.1 \mathrm{sec}$. and a rest period of $0.9 \mathrm{sec}$. The specimens were compacted to maximum dry density at optimum moisture content. Specimens were about $200 \mathrm{~mm}$ high by $100 \mathrm{~mm}$ in diameter. Three to five specimens were tested for each gradation. Test results were collected and analyzed by computer, which is connected to resilient modulus apparatus.

Resilient modulus results usually modeled in terms of applied stresses. The conventional method of modeling $\mathrm{M}_{\mathrm{R}}$ for granular pavement materials is to relate $M_{R}$ to bulk stress. This model is recommended by the standard test method, AASHTO T 294-92I. The model is of the form:

$$
\mathrm{M}_{\mathrm{R}} / 100=\mathrm{K} 1(\theta / 100)^{\mathrm{K} 2}
$$

where

MR is the resilient modulus $(\mathrm{KPa})$ at a specific confining, $\sigma 3(\mathrm{KPa})$ and deviator stresses, $\sigma d(\mathrm{KPa})$

$\theta$ is bulk stress ( $\sigma \mathrm{d}+3 \sigma 3$ ), in $\mathrm{KPa}$, and $\mathrm{K} 1$ and $\mathrm{K} 2$ are regression constants.

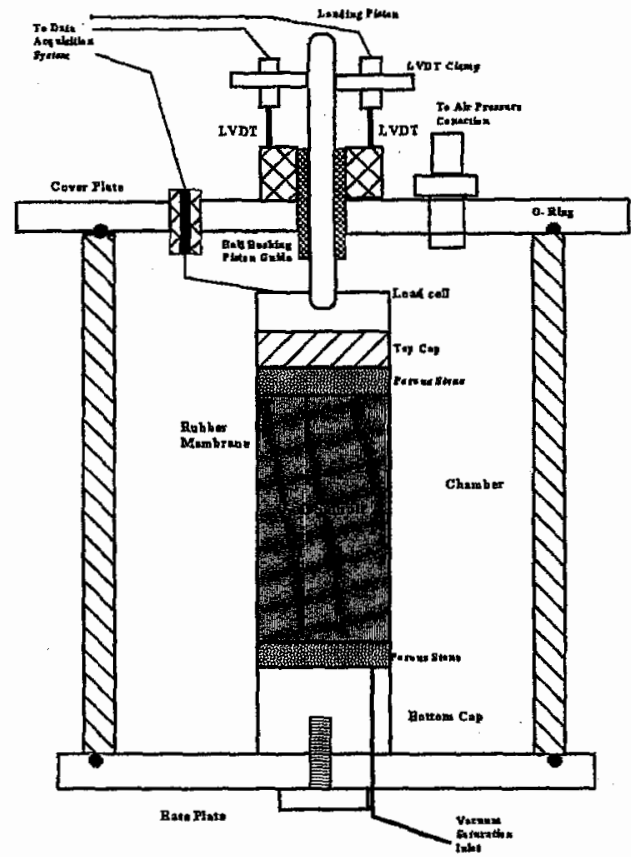

Fig. 1 Schematic Diagram of Resilient Modulus Apparatus
Both $M_{R}$ and bulk stress were divided by the atmospheric pressure $(\approx 100 \mathrm{KPa})$ in order to obtain values for $K 1$ independent of units used for $M_{R}$ and bulk stress. This model fits $M_{R}$ data relatively well and is very widely used. In this study, regression analysis was conducted between $M_{R}$ and bulk stress to obtain regression constants $\mathrm{Kl}$ and $\mathrm{K} 2$. The average correlation coefficient, $R^{2}$, for all samples is 0.713 . The average values for $K 1$ and $K 2$ for each gradation are shown in Figures 2 and 3, respectively.

The letters used in figures to indicate aggregate type refer to the first letter of the aggregate source and the first letter of gradation. For example, "cl" refers to Central aggregate and lower limit gradation. The results show that $\mathrm{K} 1$ values for the Western aggregate are about the same for all three gradations and less than those for the Central and Eastern aggregates. No clear difference between Central and Eastern aggregates. K2 values for Western aggregate, especially low limit and midpoint gradations, are somewhat higher than those for Central and Eastern aggregates. These differences could be attributed to the differences between the characteristics of Western aggregate and those of Central and Eastern aggregates such as maximum dry density, optimum moisture content and abrasion loss.

The values of $K 1$ and $K 2$ were subjected to statistical analysis to show whether there are significant differences among aggregates of various sources and gradations.

The analysis of variance (ANOVA) results are shown in Tables 5 and 6 for $\mathrm{K} 1$ and $\mathrm{K} 2$, respectively. ANOVA results for $\mathrm{K} 1$ shows that there is a significant difference among aggregates of various sources at a significance level of $95 \%$. This supports the conclusion obtained above by looking into Figure 2. Gradation, however, did not show any effect on $\mathrm{K} 1$ values.

Table 4 Testing Sequence for AASHTO Type I Soil and Base Course(AASHTO T 294-92I)

\begin{tabular}{|c|c|c|c|}
\hline $\begin{array}{c}\text { Sequence } \\
\text { No. }\end{array}$ & $\begin{array}{c}\text { Confining } \\
\text { Pressure, } \\
\text { psi (KPa) }\end{array}$ & $\begin{array}{c}\text { Deviator } \\
\text { Stress, } \\
\text { psi (KPa) }\end{array}$ & $\begin{array}{c}\text { Number of } \\
\text { Load } \\
\text { Applications }\end{array}$ \\
\hline 0 & $15(103.43)$ & $15(103.43)$ & 1,000 \\
1 & $3(20.69)$ & $3(20.69)$ & 100 \\
2 & $3(20.69)$ & $6(41.37)$ & 100 \\
3 & $3(20.69)$ & $9(62.06)$ & 100 \\
4 & $5(34.48)$ & $5(34.48)$ & 100 \\
5 & $5(34.48)$ & $10(68.95)$ & 100 \\
6 & $5(34.48)$ & $15(103.43)$ & 100 \\
7 & $10(68.95)$ & $10(68.95)$ & 100 \\
8 & $10(68.95)$ & $20(137.90)$ & 100 \\
9 & $10(68.95)$ & $30(206.85)$ & 100 \\
10 & $15(103.43)$ & $10(68.95)$ & 100 \\
11 & $15(103.43)$ & $15(103.43)$ & 100 \\
12 & $15(103.43)$ & $30(206.85)$ & 100 \\
13 & $20(137.90)$ & $15(103.43)$ & 100 \\
14 & $20(137.90)$ & $20(137.90)$ & 100 \\
15 & $20(137.90)$ & $40(275.8)$ & 100 \\
\hline
\end{tabular}




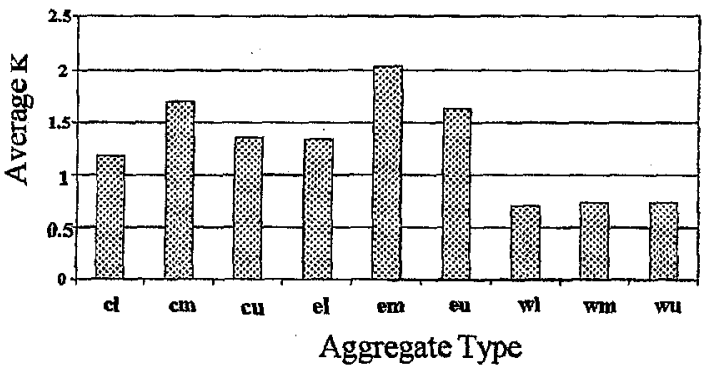

Fig. 2 Average K1 Values for Various Aggregates (Equation 1)

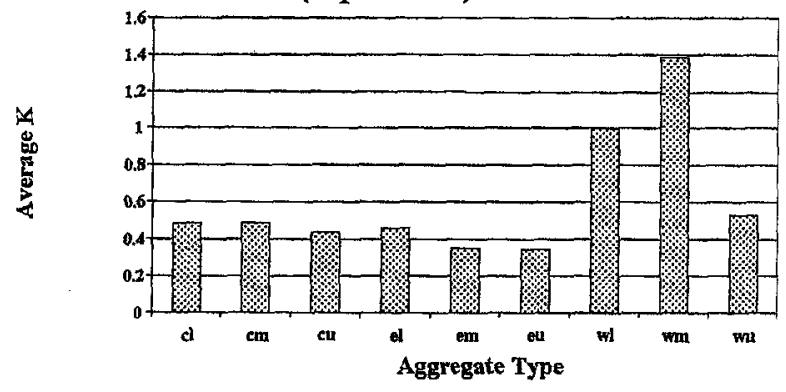

Fig. 3 Average K2 Values for Various Aggregates (Equation 1)

Table 5 Analysis of Variance for K1 (Equation 1)

\begin{tabular}{|c|c|c|c|c|c|c|}
\hline Source & DF & Seq. SS & Adj. SS & Adj. MS & F & P \\
\hline AGGR $^{1}$ & 2 & 2.856 & 2.1837 & 1.092 & 7.47 & 0.003 \\
\hline $\begin{array}{c}\text { GRAD } \\
\text { (AGGR) }\end{array}$ & 6 & 0.485 & 0.4848 & 0.081 & 0.55 & 0.763 \\
\hline Error & 26 & 3.801 & 3.8013 & 0.146 & & \\
\hline Total & 34 & 7.142 & & & & \\
\hline
\end{tabular}

AGGR = aggregate source and GRAD $=$ gradation (upper, midpoint and lower)

Table 6 Analysis of Variance for $\mathrm{K} 2$ (Equation 1)

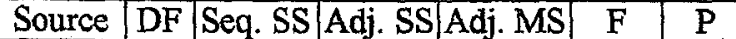

\begin{tabular}{|c|c|c|c|c|c|c|}
\hline AGGR & 2 & 0.5146 & 0.244 & 0.122 & 1.74 & 0.195 \\
\hline $\begin{array}{c}\text { GRAD } \\
\text { (AGGR) }\end{array}$ & 6 & 0.9258 & 0.926 & 0.154 & 2.20 & 0.075 \\
\hline Error & 26 & 1.8237 & 1.824 & 0.070 & & \\
\hline Total & 34 & 3.2641 & & & & \\
\hline
\end{tabular}

Results of pairwise comparison of $\mathrm{K} 1$ and $\mathrm{K} 2$ values are shown in Tables 7 and 8, respectively. For $\mathrm{K} 1$ values, Table 7 shows that Western aggregate is significantly different from both Central and Eastern aggregates. No significant differences were found between Central and Eastern aggregates. For K2 values (Table 8) no significant differences were found among aggregates at $95 \%$ significance level.

Rafael Pezo (1993) suggested a general model (named here model 2) that can be used for both granular as well as fine grained pavement materials. The model relates $M_{R}$ to both confining as well as deviator stress. The model was found to have better fitting capability than the above-mentioned model (model 1 above) (e.g. Al-Suhaibani et al., 1997). The model is of the form:
$\mathrm{M}_{\mathrm{R}} / 100=\mathrm{K} 3\left(\sigma_{d} / 100\right)^{\mathrm{K} 4}\left(\sigma_{3} / 100\right)^{\mathrm{K} 5}$

where all parameters were as defined earlier.

Table 7 Pairwise Comparisons for K1 Among Levels of AGGR (Equation 1)

\begin{tabular}{|c|c|c|c|c|}
\hline \begin{tabular}{|l|} 
AGGR $=$ \\
C* \\
subtracted \\
from: \\
\end{tabular} & \multirow[t]{2}{*}{$\begin{array}{l}\text { Difference } \\
\text { of Means }\end{array}$} & \multirow[t]{2}{*}{$\begin{array}{c}\text { SE of } \\
\text { Difference }\end{array}$} & \multirow[t]{2}{*}{ T-Value } & \multirow[t]{2}{*}{$\begin{array}{l}\text { Adjusted } \\
\text { P-Value }\end{array}$} \\
\hline $\begin{array}{l}\text { Level } \\
\text { AGGR: }\end{array}$ & & & & \\
\hline $\mathrm{E}^{*}$ & 0.2559 & 0.1678 & 1.525 & 0.2960 \\
\hline $\mathrm{W}^{*}$ & -0.4213 & 0.1587 & -2.655 & 0.0345 \\
\hline $\begin{array}{l}\mathrm{AGGR}=\mathrm{E} \\
\text { subtracted } \\
\text { from: } \\
\mathrm{W}^{*}\end{array}$ & -0.6772 & 0.1795 & -3.773 & 0.0024 \\
\hline
\end{tabular}

* C, E and W refer to Central, Eastern and Western sources of aggregates, respectively

In this model, the effect of deviator and confining stresses on $M_{R}$ were separated. As for model 1 above, $\mathrm{M}_{\mathrm{R}}$ and deviator and bulk stresses were divided by atmospheric pressure $(\approx 100 \mathrm{KPa})$ in order for $\mathrm{K} 3$ to be dimensionless. $\mathrm{K} 3, \mathrm{~K} 4$ and $\mathrm{K} 5$ were determined from regression analysis. The model fits almost all data very well. The average $R^{2}$ is 0.84 . This value is higher than the average $R^{2}$ for Equation $1(0.71)$ above, indicating preference of Equation 2 over Equation 1.

Table 8 Pairwise Comparisons for K2 Among Levels of AGGR (Equation 1)

\begin{tabular}{|c|c|c|c|c|}
\hline $\begin{array}{l}\text { AGGR = } \\
\mathrm{C} \\
\text { subtracted } \\
\text { from: }\end{array}$ & $\begin{array}{l}\text { Difference } \\
\text { of Means }\end{array}$ & $\begin{array}{c}\text { SE of } \\
\text { Difference }\end{array}$ & $T$-Value & $\begin{array}{l}\text { Adjusted } \\
\mathrm{P} \text {-Value }\end{array}$ \\
\hline \begin{tabular}{|l|} 
Level \\
AGGR \\
\end{tabular} & & & & \\
\hline$E$ & -0.04053 & 0.1162 & -0.3487 & 0.9353 \\
\hline W & 0.16969 & 0.1099 & 1.5439 & 0.2876 \\
\hline \begin{tabular}{|l} 
AGGR = \\
E \\
subtracted \\
from: \\
W
\end{tabular} & 0.2102 & 0.1243 & 1.691 & 0.2277 \\
\hline
\end{tabular}

Bar charts for $\mathrm{K} 3, \mathrm{~K} 4$ and $\mathrm{K} 5$ values are shown in Figures 4,5 and 6 , respectively. There is no clear variation of $\mathrm{K} 3$ values as either aggregate or gradation change. However, $\mathrm{K} 3$ values seem to be less for Western than those for Central and Eastern aggregates.

Figure 5 shows that $\mathrm{K} 4$ value for each aggregate type decrease as gradation gets finer. As for the effect of aggregate type, Western aggregate has higher $\mathrm{K} 4$ values than the other two aggregates. In other words, the effect of deviator stress on $M_{R}$ gets higher as gradation becomes coarser. Furthermore, deviator stress has more effect on $M_{R}$ for Western aggregate than for the others. 
Abdulrahman Al-Suhaibani, "Effect of Aggregate Source and Gradation on The Resilient Behovior of ......... "

Figure 6 shows effect of aggregate type and gradation on K5. For a given aggregate, and with the exception of upper limit gradation for Western aggregate, $\mathrm{K} 5$ increases as gradation becomes finer. $\mathrm{K} 5$ is an index of confining stress effect on $\mathrm{M}_{R}$. This behavior could be due to the higher optimum moisture content for finer gradations.

$\mathrm{K} 3, \mathrm{~K} 4$ and $\mathrm{K} 5$ data were subjected to analysis of variance (ANOVA) to investigate whether there is a significant difference among their means for various aggregates. Table 9 shows the ANOVA results for K3. Values in the table indicate a significant difference among $\mathrm{K} 3$ values for different aggregates at $95 \%$ significant level. However, pairwise comparison shows that the significant difference is only between Eastern and Western aggregates (Table 10). Differences in K3 within each aggregate type are not significant as seen in Table 9. Tables 11 through 14 present the ANOVA and pairwise comparison results for $\mathrm{K} 4$ and $\mathrm{K} 5$. For both parameters, no significant differences were found among the three aggregate types. However, there are significant differences within each aggregate type (between gradations). This conclusion agrees with that obtained from bar charts above.

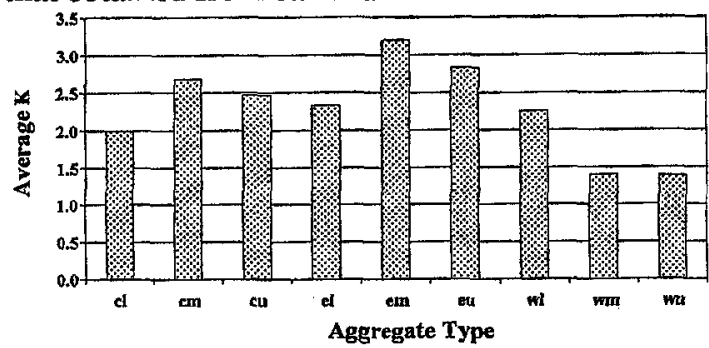

Fig. 4 Average $\mathrm{K} 3$ Values for Various Aggregates (Equation 2)

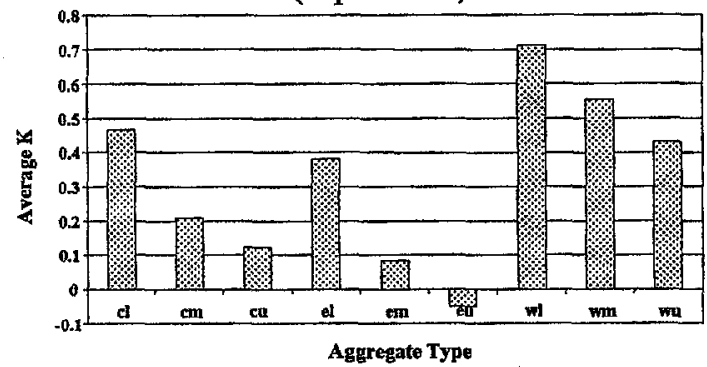

Fig. 5 Average K4 Values for Various Aggregates (Equation 2)

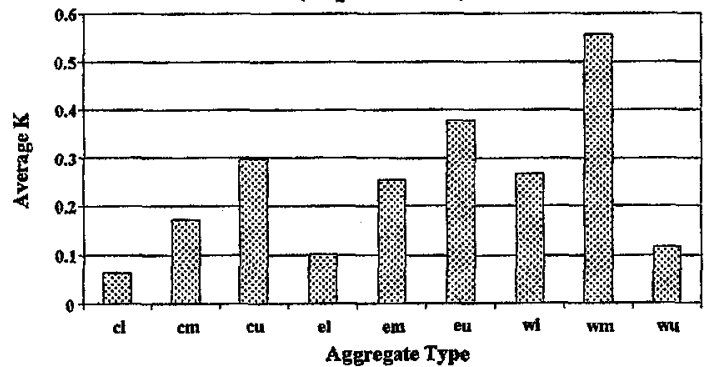

Fig. 6 Average K5 Values for Various Aggregates (Equation 2)
Table 9 Analysis of Variance for K3 (Equation 2)

\begin{tabular}{|c|c|c|c|c|c|c|}
\hline Source & DF & Seq. SS & Adj. SS & Adj. MS & F & P \\
\hline AGGR & 2 & 4.813 & 4.798 & 2.399 & 4.27 & 0.024 \\
\hline $\begin{array}{c}\text { GRAD } \\
\text { (AGGR) }\end{array}$ & 6 & 4.955 & 4.955 & 0.826 & 1.47 & 0.224 \\
\hline Error & 29 & 16.31 & 16.31 & 0.563 & & \\
\hline Total & 37 & 26.08 & & & & \\
\hline
\end{tabular}

Table 10 Pairwise Comparisons for K3 Among Levels of AGGR (Equation 2)

\begin{tabular}{|c|c|c|c|c|}
\hline $\begin{array}{l}\text { AGGR =C } \\
\text { subtracted } \\
\text { from: }\end{array}$ & \multirow[t]{2}{*}{$\begin{array}{l}\text { Difference } \\
\text { of Means }\end{array}$} & \multirow[t]{2}{*}{$\begin{array}{c}\mathrm{SE} \text { of } \\
\text { Difference }\end{array}$} & \multirow[t]{2}{*}{ T-Value } & \multirow[t]{2}{*}{$\begin{array}{l}\text { Adjusted } \\
\text { P-Value }\end{array}$} \\
\hline \begin{tabular}{|l|} 
Level \\
AGGR
\end{tabular} & & & & \\
\hline $\mathrm{E}$ & 0.3756 & 0.3045 & 1.234 & 0.4435 \\
\hline $\mathrm{W}$ & -0.5291 & 0.2940 & -1.799 & 0.1876 \\
\hline $\begin{array}{l}\text { AGGR = E } \\
\text { subtracted } \\
\text { from: } W\end{array}$ & -0.9047 & 0.3129 & -2.891 & 0.0192 \\
\hline
\end{tabular}

Table 11 Analysis of Variance for K4 (Equation 2)

\begin{tabular}{|c|c|c|c|c|c|c|}
\hline Source & $D F$ & Seq. SS & Adj. SS & Adj. MS & F & $P$ \\
\hline AGGR & 2 & 0.49757 & 0.38274 & 0.19137 & 2.29 & 0.122 \\
\hline $\begin{array}{l}\text { GRAD } \\
\text { (AGGR) }\end{array}$ & 6 & 1.62227 & 1.62227 & 0.27038 & 3.23 & 0.017 \\
\hline Error & 26 & 2.17618 & 2.17618 & 0.0837 & & \\
\hline ta & 34 & 4.29601 & & & & \\
\hline
\end{tabular}

Table 12 Pairwise Comparisons for K4 Among Levels of AGGR (Equation 2)

\begin{tabular}{|c|c|c|c|c|}
\hline $\begin{array}{l}\text { AGGR = } \\
\text { C } \\
\text { subtracted } \\
\text { from: }\end{array}$ & $\begin{array}{l}\text { Difference } \\
\text { of Means }\end{array}$ & $\begin{array}{c}\text { SE of } \\
\text { Difference }\end{array}$ & T-Value & $\begin{array}{l}\text { Adjusted } \\
\text { P-Value }\end{array}$ \\
\hline \begin{tabular}{|l|} 
Level \\
AGGR \\
\end{tabular} & & & & \\
\hline $\mathrm{E}$ & -0.1680 & 0.1194 & -1.407 & 0.3519 \\
\hline W & 0.1024 & 0.1239 & 0.827 & 0.6902 \\
\hline $\begin{array}{l}\text { AGGR = } \\
\text { E } \\
\text { subtracted } \\
\text { from: } \\
\text { W }\end{array}$ & 0.2704 & 0.1288 & 2.100 & 0.1095 \\
\hline
\end{tabular}

Table 13 Analysis of Variance for K5 (Equation 2)

\begin{tabular}{|l|c|c|c|c|c|c|}
\hline Source & DF & Seq. SS & Adj. SS & Adj. MS & F & P \\
\hline AGGR & 2 & 0.02963 & 0.03455 & 0.01728 & 0.58 & 0.566 \\
\hline $\begin{array}{l}\text { GRAD } \\
\text { (AGGR) }\end{array}$ & 6 & 0.55135 & 0.55135 & 0.09189 & 3.09 & 0.020 \\
\hline Error & 26 & 0.77237 & 0.77237 & 0.02971 & & \\
\hline Total & 34 & 1.35335 & & & & \\
\hline
\end{tabular}


Table 14 Pairwise Comparisons for K5 Among Levels of AGGR(Equation 2)

\begin{tabular}{|l|l|l|l|l|}
\hline $\begin{array}{l}\text { AGGR } \\
\begin{array}{l}\text { subtracted } \\
\text { from: }\end{array}\end{array}$ & $\begin{array}{l}\text { Difference } \\
\text { of Means }\end{array}$ & $\begin{array}{l}\text { SE of } \\
\text { Difference }\end{array}$ & T-Value & $\begin{array}{l}\text { Adjusted } \\
\text { P-Value }\end{array}$ \\
\hline Level & & & & \\
\hline AGGR & & & & \\
\hline E & 0.07451 & 0.07114 & 1.0474 & 0.5545 \\
\hline W & 0.01697 & 0.07380 & 0.2299 & 0.9713 \\
\hline $\begin{array}{l}\text { AGGR } \\
\begin{array}{l}\text { E } \\
\text { subtracted } \\
\text { from: } \\
\text { W }\end{array}\end{array}$ & -0.05754 & 0.07672 & -0.7500 & 0.7363 \\
\hline
\end{tabular}

\section{RELATING $M_{\mathrm{R}}$ MODELS CONSTANTS TO} AGGREGATE PROPERTIES

There have been several attempts (e.g. Rada, G. and Witczak, M. 1981; Tian, P. et al., 1998; Mohammad, $L$. et al. 1999) to relate $M_{R}$ of pavement materials to their physical properties, either by relating $\mathrm{M}_{\mathrm{R}}$ directly or by relating the constants of $M_{R}$ predictive equation to material's properties. Stepwise regression was used to relate $\mathrm{K} 3, \mathrm{~K} 4$ and K5 values to one or more of aggregate physical properties, namely; optimum moisture content, maximum dry density, water absorption, bulk specific gravity, apparent specific gravity, CBR and unconfined compressive strength. The obtained equations are as follows:

$\mathrm{K} 3=67.1-13.13 * \mathrm{APP}-6.96 * \mathrm{MDD}-2.554 * \mathrm{OMC}$

$$
+0.03896 * Q
$$

where

APP = apparent specific gravity, $\mathrm{MDD}=$ maximum dry density, $\mathrm{OMC}=$ optimum moisture content, $\mathrm{Q}=$ unconfined compressive strength

$\begin{array}{lll}\mathrm{R}^{2}=0.915 & \text { Adj. } \mathrm{R}^{2}=0.83 & \mathrm{SE}=0.252 \\ \mathrm{~F}=10.74 & \text { Sig. } \mathrm{F}=0.0205\end{array}$

$\mathrm{K} 4=-0.016+1.92 * \mathrm{APP}-0.0129^{*} \mathrm{Q}$

where

$\mathrm{APP}$ and $\mathrm{Q}$ as defined above

$\mathrm{R}^{2}=0.956 \quad$ Adj. $\mathrm{R}^{2}=0.942 \quad \mathrm{SE}=0.06$

$F=65.36 \quad$ Sig, $F=0.0001$

$\mathrm{K} 5=-4.815+0.337 * \mathrm{ABSRP}+1.675 *$ Bulk

where

$\mathrm{ABSRP}=$ water absorption, Bulk = bulk specific gravity.

$\mathrm{R}^{2}=0.453 \quad$ Adj. $\mathrm{R}^{2}=0.27 \quad \mathrm{SE}=0.132$

$F=2.48 \quad$ Sig. $F=0.164$

Although one of the predictive equations has relatively low coefficient of determination, these equations do give indication of the importance of the independent variables in affecting $\mathrm{M}_{\mathrm{R}}$ behavior of tested aggregates. The best predictive equation is that of K4 (equation 4), which explains the role of deviator stress on $M_{R}$ behavior. Apparent specific gravity and unconfined compressive strength are the aggregate properties that explain most this role of deviator stress on $M_{R}$. The next best equation is that for $K 3$ that represents the constant term in $M_{R}$ equation. Below each equation are regression results that show how much variability of $\mathrm{Ks}$ is explained by the independent variables and the goodness of the equations in predicting the correct $\mathrm{Ks}$ values.

\section{CONCLUSIONS}

1. Analysis of variance of $\mathrm{Kl}$ values (Equation 1) shows a significant effect for aggregate type on these values. However, no significant effect was found for aggregate gradation.

2. Results of pairwise comparison of $\mathrm{K} 1$ and $\mathrm{K} 2$ values show that, for $K 1$ values, Western aggregate is significantly different from both Central and Eastern aggregates. However, no significant differences were found between $\mathrm{K} 1$ values for Central and Eastern aggregates, For K2 values, no significant differences were found among aggregates at $95 \%$ significance level.

3. There is significant difference among $\mathrm{K} 3$ values for different aggregates at $95 \%$ significant level. However, pairwise comparison shows that the significant difference is only between Eastern and Western aggregates.

4. Results for $\mathrm{K} 4$ and $\mathrm{K} 5$ show that no significant differences among the three aggregate types. However, there are significant differences between gradations for various aggregates.

5. With the exception of upper limit gradation for Western aggregate, K5 increases as gradation becomes finer.

6. K4 value for each aggregate type decreases as gradation gets finer.

7. For the effect of aggregate type, Western aggregate has higher $\mathrm{K} 4$ values than the other two aggregates. In other words, the effect of deviator stress on $M_{R}$ gets higher as gradation becomes coarser.

8. Deviator stress has more effect on $M_{R}$ for Western aggregate than for the other types.

9. There is no clear variation of $\mathrm{K} 3$ values as either aggregate type or gradation change. However, K3 values seem to be less for Western aggregate than those for Central and Eastern aggregates.

10. By relating $\mathrm{Ks}$ values to aggregate properties, it was found that the best predictive Equation is that of $\mathrm{K} 4$ (equation 4), which explains the role of deviator stress on $M_{R}$ behavior. Apparent specific gravity and unconfined compressive strength are the aggregate properties that explain most the role of deviator stress on $\mathrm{M}_{\mathrm{R}}$.

11. The next best equation is that of $\mathrm{K} 3$ that represents the constant term in $\mathrm{M}_{\mathrm{R}}$ equation. 


\section{REFERENCES}

[1] Al-Suhaibani, A., Al-Refeai, T. and Noureldin, A. S. (1997), "Characterization of Subgrade Soils in Saudi Arabia; A Study of Resilient Behavior," Final Report submitted to King Abdulaziz City for Science and Technology (KACST), Project No. AR-12-51, Riyadh, Saudi Arabia.

[2] Chen, D., Zaman, M. and Laguros, J. (1994), " Resilient Moduli of Aggregate Materials: Variability Due to Testing Procedure and Aggregate Type," paper presented at the $73^{\text {rd }}$ Annual Meeting of Transportation Research Board, January 9-11, Washington, D.C.

[3] Heydinger, A., Xie, Q., Randolph, B. and Gupta, J. (1997), "Analysis Of Resilient Modulus of Dense- and Open-Graded Aggregate," Transportation Research Record 1547, Transportation Research Board, Washington, D.C., pp. 1-6.

[4] Mohammad, L., Huang, B., Puppala, A. and Allen, A. (1999), "A Regression Model for Resilient Modulus of Subgrade Soils," paper presented at the $78^{\text {th }}$ Annual Meeting of Transportation Research Board, January 11-14, Washington, D.C.
[5] Pezo, R. F. (1993), "A General Method of Reporting Resilient Modulus Tests of Soils. A Pavement Engineer's Point of View," paper presented at the $72^{\text {nd }}$ Annual Meeting of Transportation Research Board, January 10-14, Washington, D.C.

[6] Rada, G. and Witczak, M. (1981), "Comprehensive Evaluation of Laboratory Resilient Moduli Results For Granular Material," Transportation Research Record 810, Transportation Research Board, Washington, D.C., pp. 23-33.

[7] Tian, P., Zamman, M. and Laguros, J. (1998), "Gradation And Moisture Effects on Resilient Modulus of Aggregate Bases," paper presented at the $77^{\text {th }}$ Annual Meeting of Transportation Research Board, January 11-15, Washington, D.C.

[8] Uzan, J. (1985), "Characterization of Granular Material," Transportation Research Record 1022, Transportation Research Board, Washington, D.C., pp. 52-59. 